\title{
Mineração, degradação ambiental e arqueologia. Minas Gerais, Brasil século XVIII
}

\section{( Carlos Magno Guimarães* Camila Fernandes de Morais**}

Fecha de recepción: 7 de diciembre de 2017. Fecha de aceptación: 10 de junio de 2018

\section{Resumo}

Palavras chave patrimônio arqueológico recuperação ambiental arqueologia período colonial

A partir do final do século XVII a região central do Brasil foi palco de um intenso processo de exploração mineral -ouro e diamantes- que passou à história, identificado através da denominação de "Ciclo do Ouro". Utilizando técnicas desenvolvidas em função das condições ambientais, a atividade mineraria provocou impactos no ambiente/ paisagem que ainda hoje podem ser identificados como vestígios arqueológicos. A destruição da cobertura vegetal, as alterações radicais no relevo, o assoreamento e o ressecamento dos cursos d'água, são alguns dos impactos provocados por aquele processo extrativo. As antigas áreas exploradas apresentam hoje evidências de um processo natural de recuperação colocando os vestígios arqueológicos na condição de elementos a serem preservados, tanto na perspectiva patrimonial quanto ambiental. Este trabalho pretende abordar a forma como tais vestígios se apresentam bem como sua relevância para o estudo da história da mineração, da degradação ambiental e da questão patrimonial.

Mining, environmental degradation and archeology. Minas Gerais, Brazil $18^{\text {th }}$ century

\section{Abstract}

Key-words

archaeological heritage environmental recovery archaeology colonial period
By late 17th century Brazil's central region was the scenario of an intensive process of mineral exploitation -gold and diamonds- which came to be known as "Golden Cycle". Using techniques developed due to environmental conditions, the mining activity provoked impact on the landscape and environment which can be identified as archaeological records at present. Destruction of the vegetation cover, radical changes in the natural form of the land, the silting and dryness of watercourses are some of the consequences the extraction process

\footnotetext{
* Laboratório de Arqueologia da Faculdade de Filosofia e Ciências Humanas, Universidade Federal de Minas Gerais (UFMG). Belo Horizonte, Minas Gerais - Brasil. E-mail: carlosmagnoguimaraes@yahoo.com.br

** Laboratório de Arqueologia da Faculdade de Filosofia e Ciências Humanas, Universidade Federal de Minas Gerais (UFMG). Belo Horizonte, Minas Gerais - Brasil. E-mail: cafernandes.morais@gmail.com
} 
caused. Nowadays, the old exploited areas present evidences of a natural recovery, placing the archaeological remains as elements to be preserved, both from a patrimonial and environmental perspective. This paper studies the way in which these vestiges are presented as well as its relevance for the study of the history of mining, environmental degradation and patrimonial issues.

\section{Introdução}

Neste trabalho abordamos alguns tipos de vestígios arqueológicos remanescentes dos processos de mineração no contexto das Minas Gerais, Brasil, do século XVIII, bem como a relevância deles para o estudo da história da mineração, da degradação ambiental e da questão patrimonial.

Inicialmente são referidas e contextualizadas tipos de atividades extrativas ocorridas nas minas coloniais e que envolveram diferentes modalidades de impactos no ambiente. Em sua dinâmica histórica cada sociedade interage com o meio de maneira única, criando formas específicas de sobrevivência através de recursos, técnicas e dinâmicas sociais que se processam no ambiente onde estão implantadas. Nesses contextos foram produzidos parte dos vestígios arqueológicos abordados neste trabalho. Mas os vestígios aqui apresentados remanescentes do período tradicionalmente identificado como Ciclo do Ouro, estão relacionados também à agropecuária e à rebeldia escrava -através da presença do quilombo do Ambrósio.

Tais dados foram coletados através de pesquisas realizadas pelo Centro Especializado de Arqueologia Histórica do Museu de História Natural e Jardim Botânico e pelo Laboratório de Arqueologia da Faculdade de Filosofia e Ciências Humanas da Universidade Federal de Minas Gerais.

\section{Contexto histórico}

Com relação aos descobertos auríferos, Portugal não teve inicialmente a mesma condição que a Espanha nas suas colônias americanas. As ricas e cobiçadas minas de ouro só foram localizadas pelos bandeirantes paulistas nos sertões das Minas Gerais, nos últimos anos do século XVII. A denominação Minas Gerais era utilizada para identificar uma vasta região do sertão brasileiro, que se estendia pelos atuais estados de Minas Gerais, Goiás e Mato Grosso, tendo o primeiro se destacado como a maior área produtiva (Imagem 1).

As notícias das ricas jazidas rapidamente se espalharam pela Colônia e Metrópole, gerando um grande fluxo populacional para a região. O intenso deslocamento da população foi responsável pela ocupação do território colonial e, em pouco tempo, os principais núcleos -Vila Rica (Ouro Preto), Nossa Senhora do Carmo (Mariana) e Vila Real do Sabará (Sabará)- estavam consolidados e explorados por pessoas de diferentes origens e condições.

A descoberta desencadeou uma intensificação do tráfico de escravos e a integração de outras áreas da Colônia, na condição de fornecedoras da região das minas. Surgiu uma sociedade fortemente hierarquizada que teve na escravidão a forma dominante de organização do trabalho e da exploração, tanto dos seres humanos quanto dos recursos naturais. Era uma sociedade constituída por três grandes grupos étnicos, como indígenas, africanos e europeus. Cada um destes grupos apresentava subdivisões que identificavam diferentes categorias 
1. As "negras de tabuleiro" eram profissionais que se dedicavam à produção e à venda de comestíveis -doces e salgados- e bebidas. Foram reprimidas ao longo de todo o período da atividade minerária sob a acusação de que, através de suas atividades, promoviam o desvio e o contrabando de ouro.

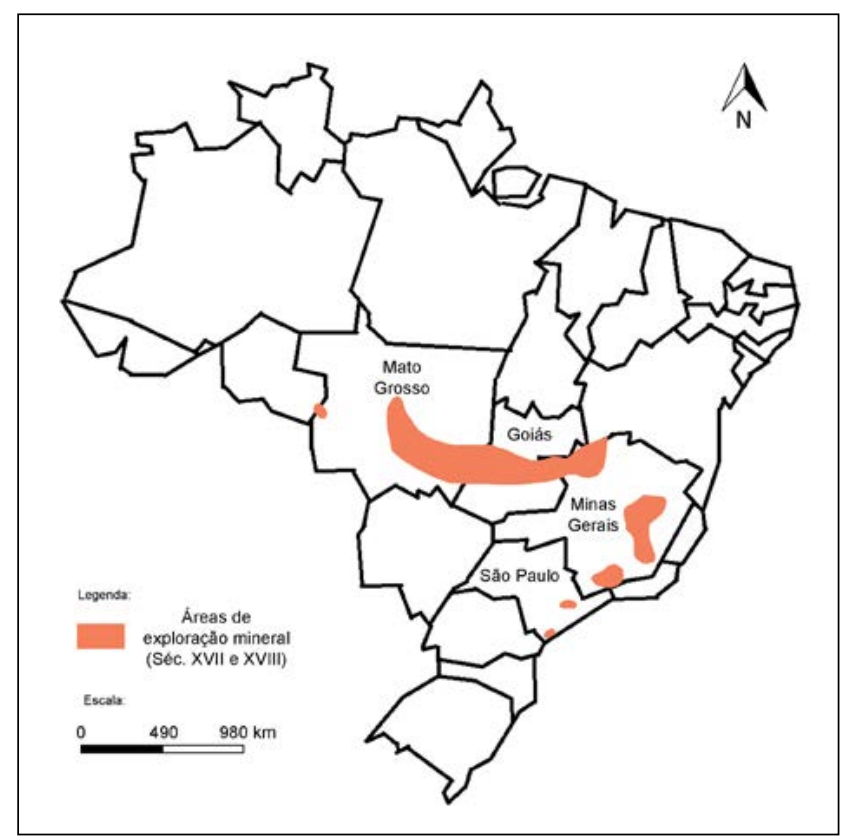

Imagem 1. Áreas de exploração mineral (séculos XVII e XVIII). Fonte, Laboratório de Arqueologia da Faculdade de Filosofia e Ciências Humanas (FaFiCh)/ Universidade Federal de Minas Gerais (UFMG).

sociais como: escravos, forros, livres, senhores, camponeses, etc. (Resende \& Villalta, 2007a e 2007b).

Embora fosse a mineração a atividade nuclear, aquela foi uma sociedade marcada pela diversidade de atividades econômicas, uma acentuada desigualdade social, uma grande diversidade cultural e uma imensa variedade de conflitos -sociais, econômicos, raciais, culturais, etc. Aquela diversidade, em muitas situações, favoreceu o estabelecimento de conflitos decorrentes de diferentes interesses. A escravidão foi uma dessas condições determinantes de conflitos, na medida em que as populações escravizadas reagiam de todas as formas às condições a elas impostas, e inúmeras foram as modalidades de rebeldia adotadas no contexto da sociedade mineira (Guimarães, 1988, 1995, 1996).

Embora certa parte da visão tradicional aponte para a mineração como atividade exclusiva na primeira metade do século XVIII, estudos demonstram outra realidade. A própria Coroa portuguesa constatou a necessidade de desenvolver atividades que pudessem servir de suporte à atividade nuclear. Ainda que as unidades minerarias abrigassem em seu interior roças para a produção de mantimentos, demandavam do setor agrário outros produtos, o que gerou a consolidação de uma produção agrícola e pastoril voltada para o abastecimento de núcleos mineradores, sendo fundamental para o seu funcionamento. (Guimarães \& L. M. Reis, 1986; Guimarães \& F. M. Reis, 2007).

Naquele contexto, foi de grande importância a presença das "negras de tabuleiro". Escravas e forras, elas circulavam pelas vilas, arraiais e roças onde ocorria a exploração do ouro vendendo suas mercadorias, estando sempre e diretamente ligadas às áreas de mineração. Essas mulheres acabaram por estabelecer redes de informações e solidariedade, participando de praticas de desvio do contrabando e de articulações com quilombos. ${ }^{1}$ 
A existência e consolidação da diversidade econômica desde o início contribuiu para evitar um declínio geral da Capitania, quando da crise da mineração na segunda metade do século XVIII. Embora aquela crise tenha estimulado investimentos na produção interna e na atuação regional, não há como negar que ela impactou o mercado interno visto que havia menor disponibilidade de moeda e grande parte das transações utilizavam o ouro.

No que se refere às técnicas aplicadas na extração aurífera, em uma perspectiva mais ampla, é possível identificar duas grandes modalidades: a mineração nos leitos e margens dos rios; e aquela praticada nas encostas dos morros (Reis, 2007).

Os cursos d'água foram tendencialmente os primeiros lugares a serem explorados, visto que o ouro de aluvião, depositado nos leitos e margens de rios, era mais facilmente obtido através de técnicas e ferramentas mais simples. Entretanto o esgotamento dessas jazidas, sobretudo nos núcleos mineradores já consolidados, apresentava a os mineiros duas possibilidades: partir para regiões desconhecidas em busca de novas jazidas aluvionais, mais fáceis de serem exploradas, ou explorar o ouro de veio nas formações rochosas e encostas.

A exploração praticada nas encostas dos morros era mais complexa e trabalhosa, uma vez que exigia grandes investimentos, tempo e mão-de-obra escrava para a implantação dos empreendimentos e realização dos serviços. Além disso, estava associada a uma maior fixação populacional com o desenvolvimento de núcleos urbanos, e estimulou diferentes setores econômicos, como a agropecuária e o comércio.

Cabe o registro de que os exploradores do período colonial não possuíam conhecimentos geológicos e mineralógicos profundos, sendo que a maior parte da categoria desconhecia o processo de formação dos veios e das matrizes rochosas auríferas; em decorrência iam em busca do metal precioso utilizando as experiências obtidas com a prática da atividade, a partir de observações empíricas.

É necessário ainda considerar que, nos primórdios da exploração, as técnicas de garimpo foram em parte pelos cativos de origem africana. Os instrumentos utilizados eram precários e o processo de exploração resultava em um intenso quadro de degradação ambiental. Na medida em que novas técnicas foram introduzidas, visando a expansão e intensidade da exploração, os processos tornaram-se mais complexos e os impactos no ambiente mais profundos e variados.

Viajantes e artistas do século XIX registraram o uso dessas técnicas e certamente sua intenção era "aprisionar", na imagem, a realidade das minas para aqueles que não pudessem constatá-la in loco. Embora sendo o desenho ou a pintura uma realidade construída pelo autor, tais representações são ricas em detalhes relacionados às técnicas, ao trabalho na mineração, às relações sociais existentes e ao ambiente -natural e social- no qual o processo se desenrolava (Paiva, 2002).

O viajante Johann Moritz Rugendas, que circulou pelo Brasil na primeira metade dos oitocentos, registrou em 1835 uma das cenas de exploração aurífera nas Minas Gerais mais conhecidas e utilizadas pela historiografia e intitulada "Lavagem do minério de ouro perto da montanha do Itacolomi" (Imagem 2). 


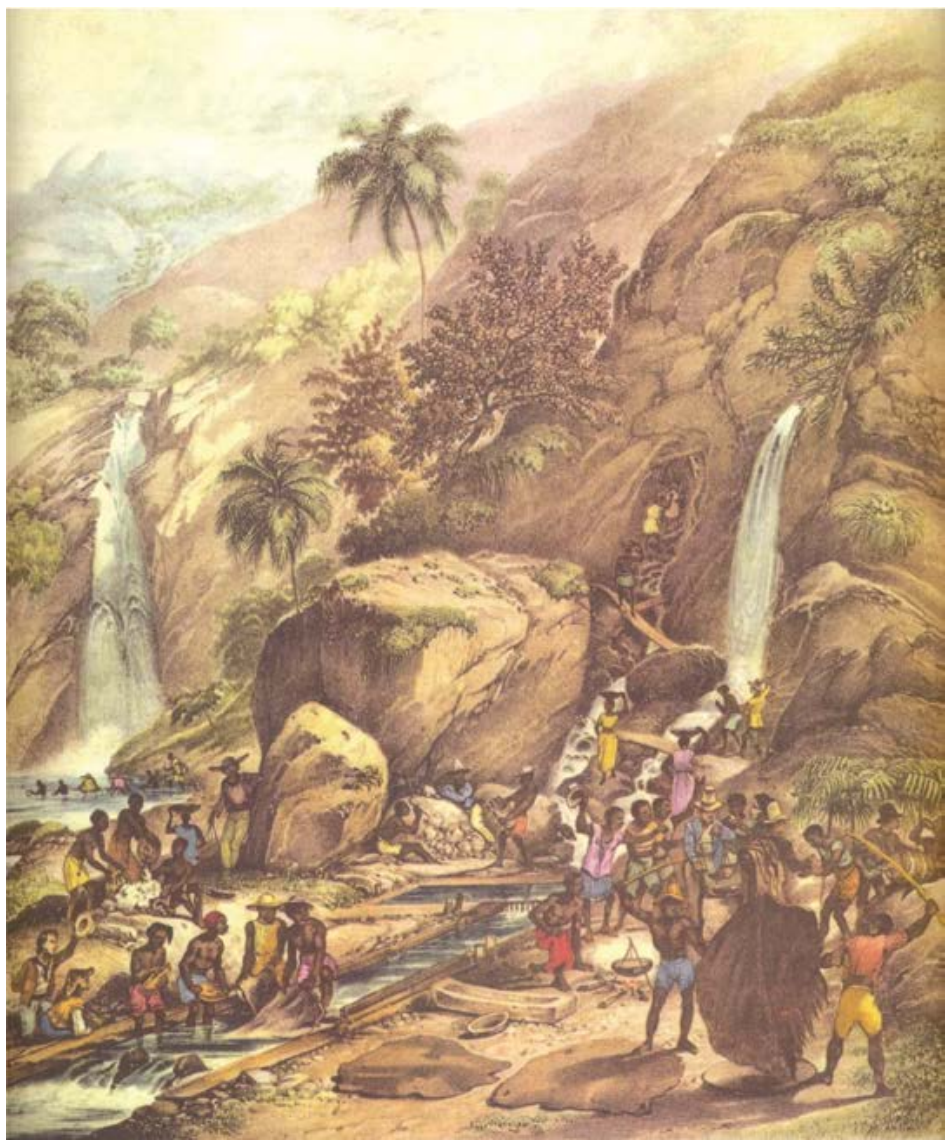

Imagem 2. “Lavagedu minerai d'or”, imagem elaborada em 1835 (Rugendas, 1998).

Independente de quais tenham sido as técnicas de mineração utilizadas, o processo extrativo nas Minas do século XVIII produziu intensas transformações no ambiente, quando considerados aspectos como a paisagem, o relevo e a hidrografia. A destruição da cobertura vegetal, o deslocamento de grandes volumes de sedimento, o ressecamento dos cursos d'água, são alguns dos mais expressivos impactos provocados pela mineração.

Muitos desses impactos podem, ainda hoje, ser percebidos no ambiente dadas as suas dimensões originais. Alguns dos vestígios arqueológicos remanescentes da mineração colonial permitem perceber a enorme capacidade que tinham os mineradores setecentistas de intervir no ambiente, como é o caso das antigas cavas de mineração e os testemunhos que sobraram do relevo original.

É inevitável reconhecer que ao longo de toda a História recente do Brasil, a atividade minerária e a degradação ambiental sempre estiveram em uma relação sistemática e permanente. Nenhuma região exemplifica melhor esta afirmativa que a região de Minas Gerais -atualmente identificada como Quadrilátero Ferrífero, quando considerados os séculos XVIII, XIX e XX.

Por outro lado, tais vestígios arqueológicos hoje -e ainda que de forma limitadacontribuem para um processo característico de recomposição ambiental e preservação da biodiversidade. Não se trata de apregoar que a degradação, no passado, inevitavelmente se torna no presente um fator de preservação. A natureza, na tentativa de superar a destruição causada pela exploração minerária -e demais atividades que a ela davam suporte-, conseguiu, em 
alguma medida, recuperar partes do ambiente destruído. E é fundamental registrar que essa recuperação não pode ser atribuída à ação humana.

Após o abandono dessas áreas exploradas é possível perceber que alguns sítios apresentam, hoje, evidências de um processo natural de recomposição que coloca os vestígios arqueológicos na condição de instrumentos a serem preservados, tanto quando são considerados na perspectiva patrimonial quanto ambiental. A seguir são apresentados alguns tipos de vestígios arqueológicos remanescentes daquelas atividades e como na atualidade eles contribuem para a recomposição ambiental e preservação da biodiversidade.

\section{Vestígios arqueológicos}

Os vestígios aqui apresentados como evidências arqueológicas resistiram ao tempo apesar do enorme impacto destrutivo que vem sofrendo nas últimas décadas. Dentre eles destacam-se: catas a céu aberto -cavas-, tanques, açudes, mundéus, canais, valos, muros de divisa, edificações e um fosso de defesa. Cada um destes tipos integrava um contexto onde cumpria funções na dinâmica social.

Durante o período/ processo aqui abordado a água foi um elemento indispensável na mineração de encosta. Todo o trabalho de desmontar as camadas de sedimento que encobriam o cascalho aurífero era realizado sob o fluxo da água articulado à força de trabalho escrava. Nos locais onde tal elemento não estava presente ou não existia em quantidade suficiente; ou ainda quando a lavra -a ser trabalhada- estava localizada acima do nível da água, trazê-la até o local de trabalho era indispensável. A solução comumente utilizada eram os canais de adução, os quais chegavam a percorrer grandes distâncias acumulando ao longo do seu percurso água captada em diferentes lugares para levá-la até a jazida.

A construção desses canais exigia uma visão espacial apurada bem como uma grande precisão técnica. Era fundamental uma adequada declividade para permitir uma vazão constante e regular da água, além de garantir a manutenção do canal. Em muitas circunstâncias a água era transportada a grandes distâncias e era necessário evitar que sua movimentação erodisse o canal.

Os canais podiam ser construídos diretamente no solo -tendo como referência, sempre que possível, as curvas de nível do terreno- ou cortados na rocha, ou ainda um misto dos dois. Muitas vezes eram revestidos ou arrimados com muros de pedras, geralmente nas curvas ou em locais mais vulneráveis à erosão. Além desses também foram comuns segmentos de canais que eram construídos de madeira sobre estruturas que permitiam o transporte da água nas áreas de relevo muito acidentado. Eram os denominados bicames.

As dimensões dos canais e o volume de água transportado variavam segundo o porte da atividade realizada, a mão de obra escrava disponível para a construção e a disponibilidade hídrica.

Além dos canais utilizados para carrear a água, havia outros destinados ao transporte da lama aurífera. Apresentavam declividade acentuada para agilizar o movimento da lama, do alto para a base da encosta onde normalmente os mundéus estavam localizados. Para esse tipo de canal, não havia a preocupação 
2. As dimensões do canal podem limitar o acúmulo de umidade e de matéria orgânica, deixando a vegetação em seu interior menos densa. com recursos técnicos que promovessem sua preservação, já que o objetivo era manter um desnível acentuado facilitando a descida da lama aurífera. Em muitas situações eram aproveitados acidentes naturais do terreno como ravinas.

Embora os canais identificados pela equipe do Laboratório de Arqueologia da Fafich/ UFMG (Imagem 3) não apresentem vegetação compacta em seu leito, devido às pequenas dimensões -largura e profundidade- ${ }^{2}$ é necessário considerar a importância desse tipo de vestígio enquanto conector de áreas de vegetação recuperada. É comum estes canais estarem ligando duas ou mais áreas de vegetação densa sendo utilizados como corredores de circulação por pequenos animais.
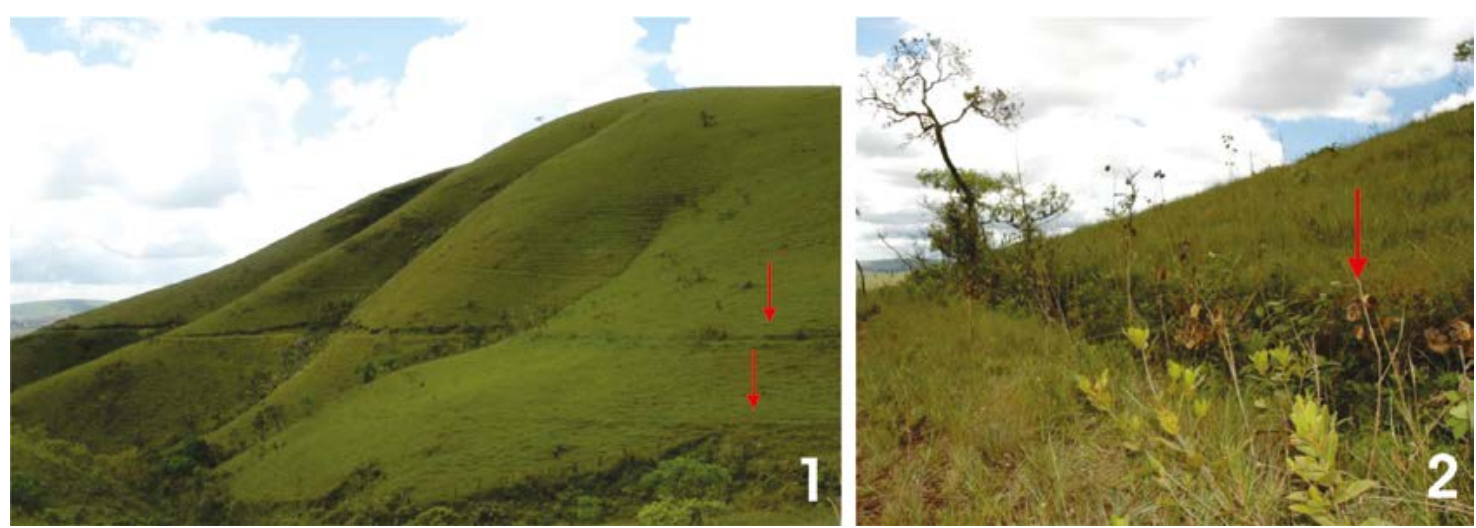

Imagem 3. 1) Segmentos de canais (setas). Arêdes (Itabirito, Minas Gerais). 2) Segmento de canal com vegetação no interior (seta). Arêdes (Itabirito, Minas Gerais).

Para garantir o adequado fornecimento da água nas áreas de exploração, grandes tanques ou açudes podiam ser construídos nas proximidades da lavra com a função de armazenamento. Eram depósitos implantados no terreno, que assim como os canais poderiam ser construídos em alvenaria, escavados no solo (Imagem 4) ou, ainda, uma mescla dos dois. Apresentavam saídas que possibilitavam o controle do fluxo de água, com o intuito de potencializar sua ação. Em intervalos de tempo jatos de água podiam ser liberados desses reservatórios, aumentando a ação sobre sedimento ou as rochas previamente fragmentadas pela ação da mão de obra escrava.

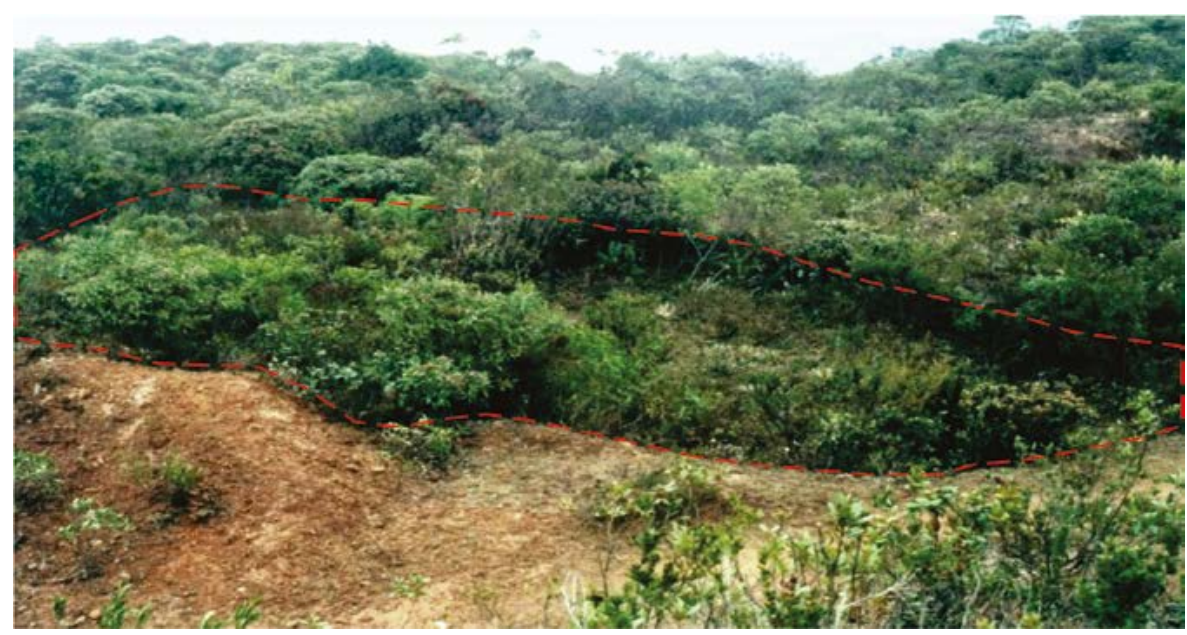

Imagem 4. Tanque. Sítio Arqueológico Morro da Queimada (Ouro Preto, Minas Gerais). 
Esses tanques podiam, ainda, ser usados para dêssedentação dos animais que eram utilizados tantos nos trabalhos da lavra quanto nas atividades-suporte, como a agricultura e a pecuária.

$\mathrm{Na}$ imagem a seguir (Imagem 5) é possível perceber como se destaca a vegetação no interior dos tanques, principalmente quando considerada sua inserção na paisagem.
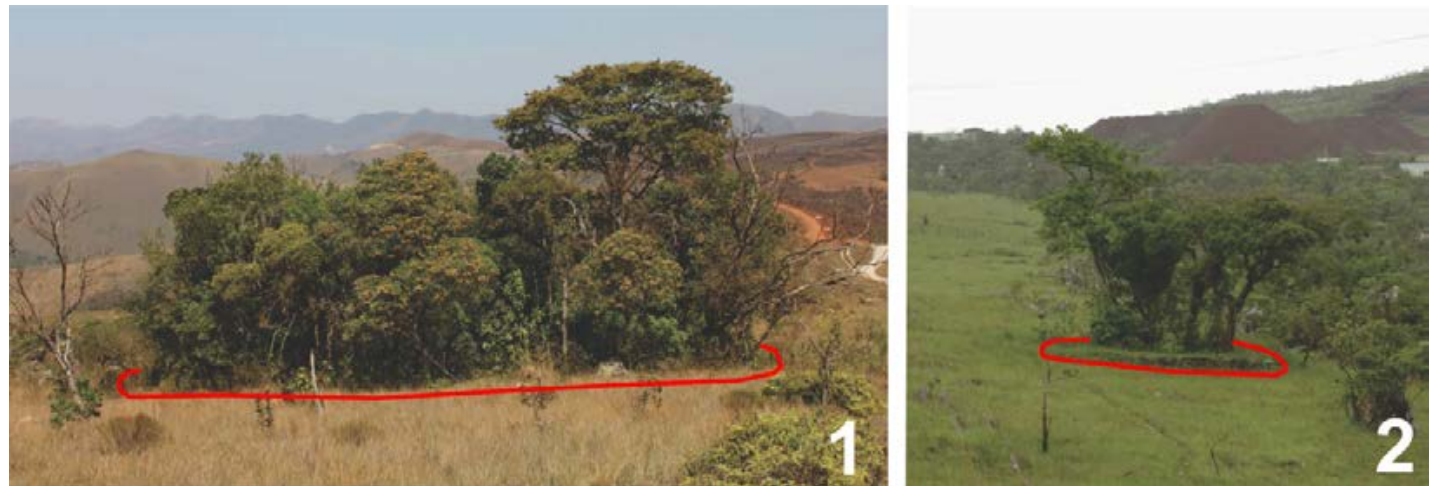

Imagem 5. 1) Tanque 1. Sítio Arqueológico Arêdes (Itabirito, Minas Gerais); 2) Tanque 2. Sítio Arqueológico Arêdes (Itabirito, Minas Gerais).

Nesses $\operatorname{casos}^{3}$ é possível perceber que no interior dos tanques escavados no terreno, as dimensões da vegetação permitem inferir maior umidade e fertilidade do solo e ainda o fato de que as queimadas anuais não interferem tanto na preservação das espécies. Esta vegetação é comumente utilizada por pássaros na época da reprodução, por constituírem lugares adequados para a implantação dos ninhos.

Além dos tanques de armazenamento de água, havia outros onde a lama aurífera era acumulada para decantação -os denominados mundéus (Imagem 6). Também eles podiam ser de alvenaria, escavados no terreno ou, ainda, um misto dos dois. Suas formas e dimensões variavam conforme o espaço disponível para sua construção e o volume da lama a ser acumulada. O que os diferencia dos outros tanques é a sua saída -para escoamento-, constituída de uma fenda vertical que podia ser vedada com pranchas de madeira assentadas horizontalmente. A retirada gradativa das pranchas permitia um escoamento rigorosamente controlado conforme as necessidades e o ritmo dos trabalhos de apuração.
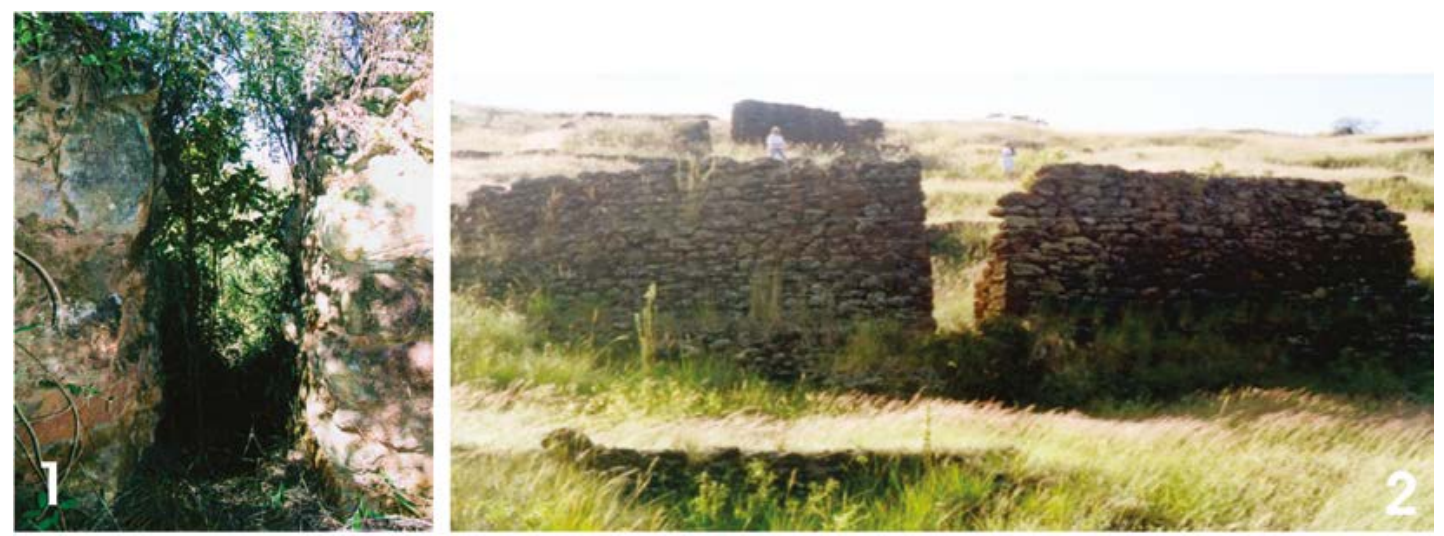

Imagem 6. 1) Saída de Mundéu. Sítio Arqueológico Forte de Brumadinho (Brumadinho, Minas Gerais). 2) Mundéus em série e detalhe da fenda (Ouro Preto, Minas Gerais).
3. Provenientes do mesmo sítio -Arêdes- no município de Itabirito, Minas Gerais. 
Quando os mundéus estavam cheios, os trabalhos de desmonte eram interrompidos e os esforços se voltavam para a etapa seguinte. Para garantir uma apuração mais eficaz, os mundéus podiam ser construídos em série para que a mesma lama passasse por mais de um processo de apuração.

Retomando a questão e tendo os tanques, açudes e mundéus como referência, cabe a constatação de que o tipo volume da vegetação presente no interior desses vestígios remete ao fato de que os muros de pedra e cortes no terreno possibilitam maior concentração de umidade e de matéria orgânica em seu interior, além de impedirem a ação do vento e das queimadas.

Se por um lado esta vegetação tem contribuído para a preservação dos vestígios, ao criar um microclima que mantém temperatura, umidade e correntes aéreas dentro de determinados limites -evitando grande amplitude térmica-; por outro lado esses vestígios ao reduzirem a ação dos ventos e das queimadas, contribuindo para preservar a vegetação em seu interior, favorecem elementos da fauna que ali vivem e se reproduzem.

As atividades descontroladas de uso e ocupação do solo, impulsionadas pelo modelo econômico vigente, têm resultado em degradação, fragmentação e esgotamento dos recursos naturais, impactando enormemente a preservação da biodiversidade. Na medida em que atuam como recursos de preservação da flora e fauna, a destruição dos vestígios arqueológicos compromete a preservação das mesmas.

Um caso exemplar ligado á afirmação acima é um tanque localizado em Arêdes -Itabirito, Minas Gerais-, que foi destruído para a implantação de uma estrada cuja finalidade é o trânsito de veículos pesados para o transporte de minério. Era um exemplar raro, por suas dimensões e pelo fato de que o sistema hidráulico do qual fazia parte estar quase inteiramente preservado.

A foto a seguir, mostra a robusta formação vegetal que existia no interior do tanque (Imagem 7). Esta certamente foi favorecida pela topografia do terreno, pela disponibilidade hídrica e pelo acúmulo de matéria orgânica. Além disso, a delimitação da estrutura com pedras e cortes no terreno certamente protegia das queimadas anuais, a vegetação em seu interior.

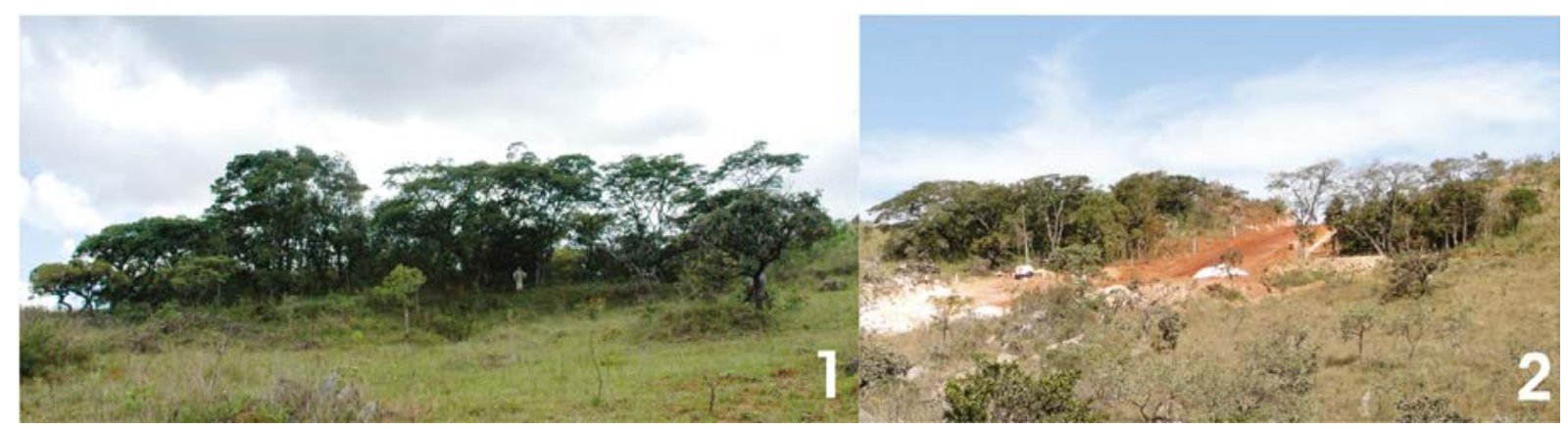

Imagem 7. 1) Vegetação no interior do tanque (2010); 2) Destruição do tanque para implantação de estrada (2015).

Enquanto vestígio arqueológico, o canal que conectava o tanque a área de lavra permite avaliar tanto o processo de captação quanto de utilização da água na atividade extrativa e em outras que a demandavam. Além disso, permite compreender como funcionavam esses sistemas hidráulicos, a partir das conexões existentes entre os diferentes elementos que o constituíam. 
Como já referido anteriormente, na atualidade estes vestígios arqueológicos -canais- funcionavam como conectores entre áreas de vegetação densa. No caso em questão, o canal ligava o tanque a uma antiga área de lavra da qual uma parte apresenta um ambiente recuperado (Imagem 8), obviamente dentro dos limites que a degradação provocada pela antiga atividade minerária permitiu. Lamentavelmente prevaleceu o interesse na construção da estrada para ligar a Mina do Pico à Mina de Fábrica -da mineradora Vale- o que significou a destruição do patrimônio arqueológico e ambiental.

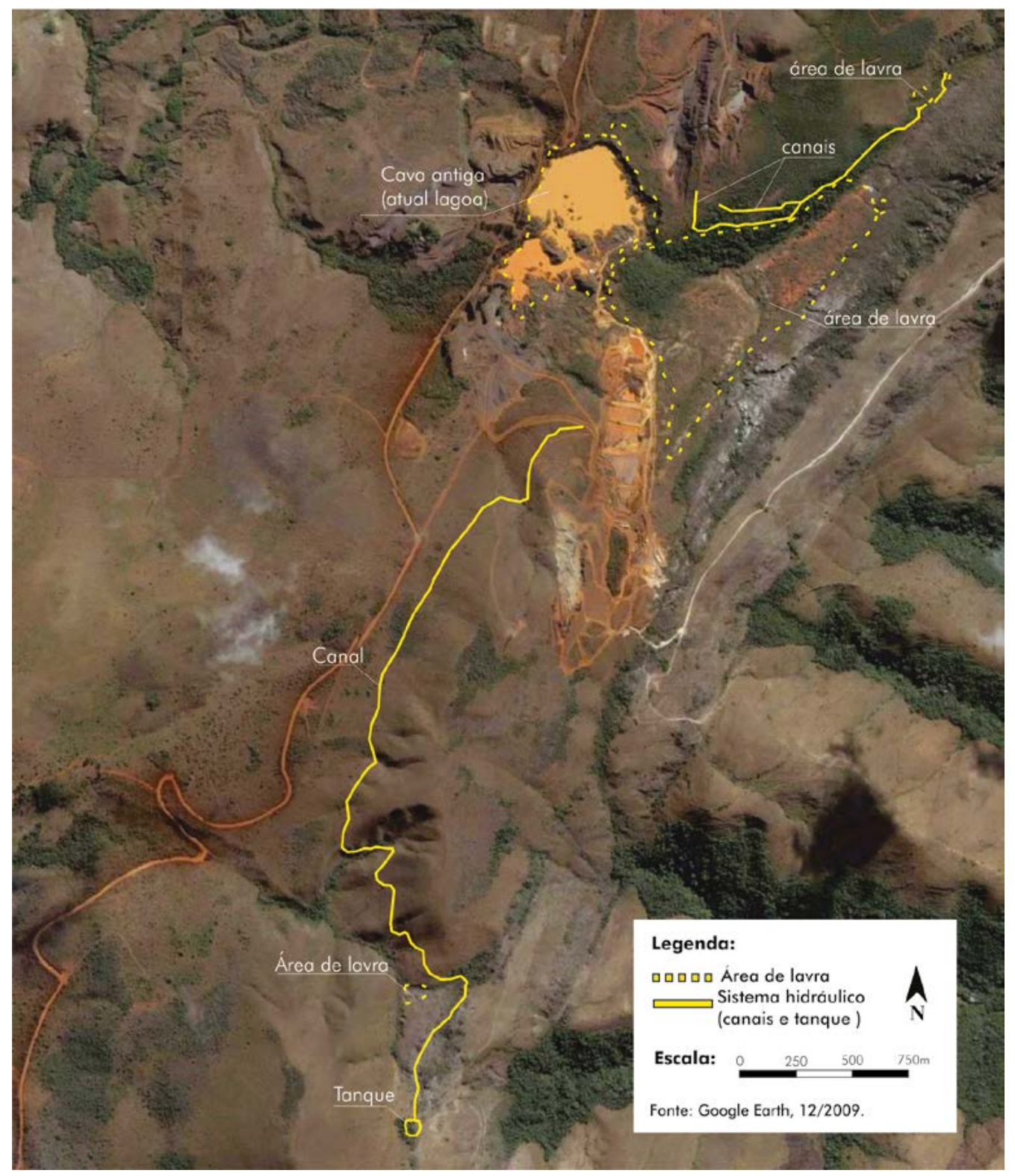

Imagem 8. Parque de Arêdes. Vestígios arqueológicos (Itabirito, Minas Gerais).

Independente de quais tenham sido as técnicas de exploração utilizadas, o processo extrativo nas Minas Gerais do século XVIII produziu intensas alterações no relevo e na paisagem, visto que exigia, dentre outras ações, a retirada da vegetação nativa e o deslocamento de grandes volumes de sedimento. 
A preparação da área a ser explorada exigia num primeiro momento a retirada da cobertura vegetal, ocasionando de imediato um enorme impacto tanto para a fauna quanto para a flora, além de tendencialmente provocar processos erosivos e redução do potencial hídrico da região.

Com relação às alterações no relevo, ainda hoje, os vestígios indicam o relevo original e é possível inferir a enorme quantidade de sedimento deslocado pela exploração minerária (Imagem 9) e o impacto provocado pela atividade, dada a sua magnitude. As antigas cavas de mineração são a evidência da grande capacidade dos mineradores setecentistas de intervir no ambiente, em razão do impacto que nele provocaram.

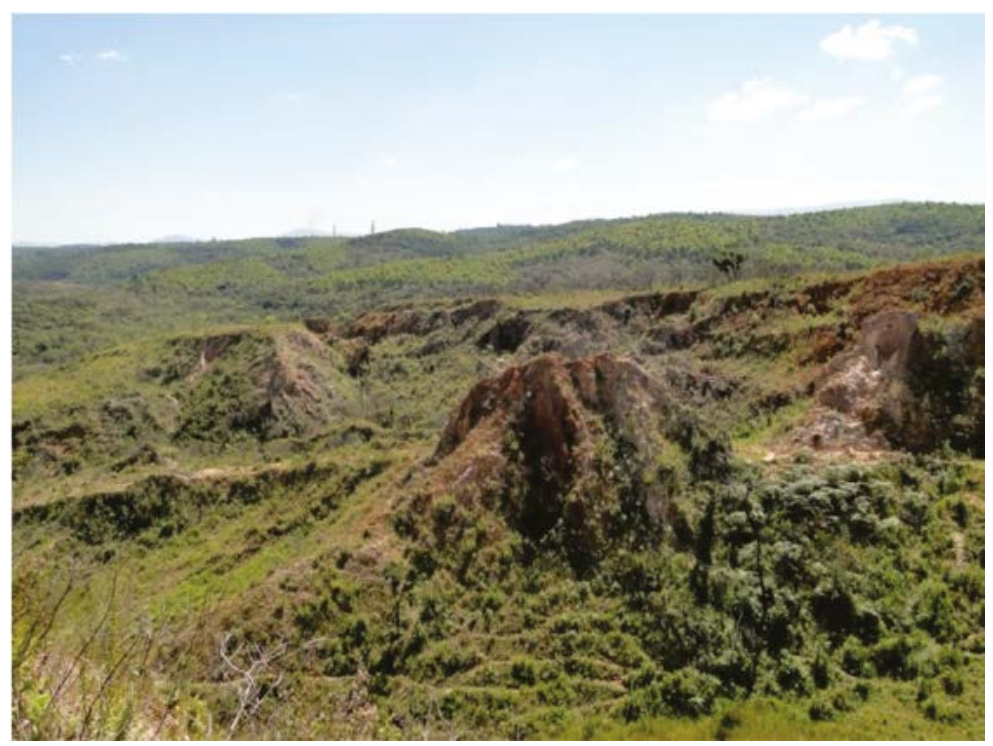

Imagem 9. Cava de mineração antiga do séc. XVIII. Sítio Arqueológico Varginha do Lourenço (Conselheiro Lafaiete, Minas Gerais).

A recuperação da vegetação nessas antigas áreas de exploração pode ocorrer, mas sempre de maneira limitada e gradual. Ainda assim esse processo é fundamental para a preservação do relevo e para o ambiente em geral, pois contribui para o controle dos processos erosivos que são decorrentes da ação de intempéries, associadas à ausência de vegetação, o que provoca um sistemático e constante desmoronamento das paredes das cavas (Imagem 10).

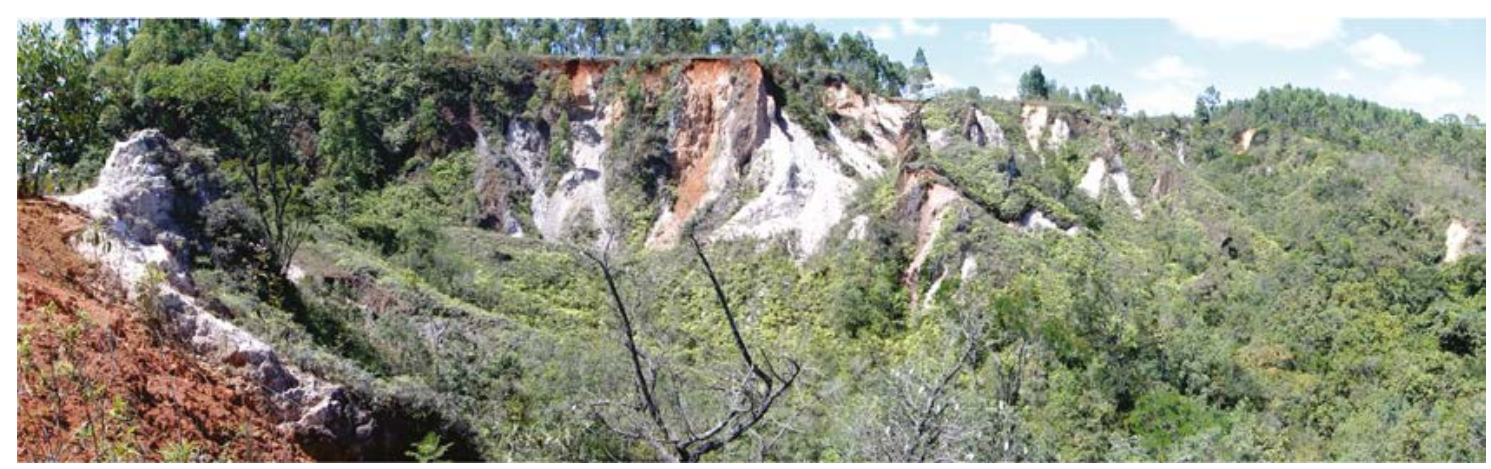

Imagem 10. Cava antiga com processo erosivo ainda em atividade. Sítio Arqueológico Varginha do Lourenço (Conselheiro Lafaiete, Minas Gerais). 
A ausência de vegetação atual está muitas vezes associada ao recorrente processo de desmatamento da mata secundária, provocando a continuidade dos processos erosivos.

A Estação Ecológica de Arêdes, no município de Itabirito, possui uma cava de mineração resultante dos processos de extração minerária no século XVIII, e que no século XX foi inundada e transformada em uma lagoa (Imagem 11).

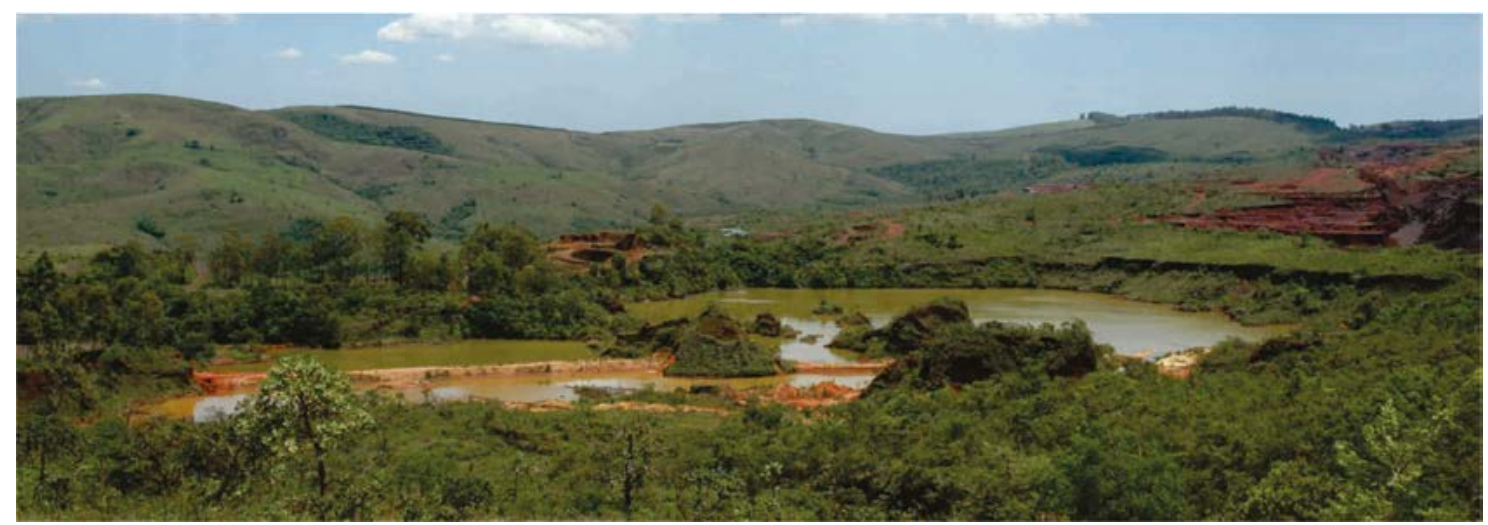

Imagem 11. Cava de mineração antiga, posteriormente inundada. Sítio Arqueológico Arêdes (Itabirito, Minas Gerais).

Além dos vestígios associados à atividade mineraria, ocorrem outros decorrestes de outras atividades. É o caso dos "valos de divisa" e de outros tipos de edificações.

Originalmente os valos de divisa eram cavidades lineares com profundidades e larguras variáveis e que cumpriam a função de delimitar as propriedades e impedir a passagem de animais de uma fazenda para outra. Assim como nos canais e nos tanques referidos anteriormente, a presença dos valos favorece em seu interior o acúmulo de matéria orgânicas e nutrientes, possibilitando ao longo do tempo sua ocupação por espécies da flora regional e servindo de habitat para certo tipo de fauna.

Ao abrigar extensas faixas de vegetação constituem elementos importantes no contexto da recuperação e conservação ambiental, funcionando como corredores que conectam fragmentos florestais, contribuindo para conservar a diversidade neles encontradas e nos ambientes aos quais estão conectados. (Castro, 2004). Entretanto, os estudos relacionados a essa realidade dos valos ainda são incipientes.

Um segmento de valo de divisa com muro de pedras, localizado na Comunidade Quilombola Chacrinha dos Pretos no município de Belo Vale -Minas Gerais, Brasil- é outro vestígio a merecer destaque, sendo complementares -o valo e o muro- por se articularem com vistas a cumprirem a mesma função. Nas imagens a seguir é possível perceber o segmento de valo -linha vermelha-, o muro de pedras -linha amarela- e uma área de vegetação mais densa ao lado do muro (Imagem 12). 


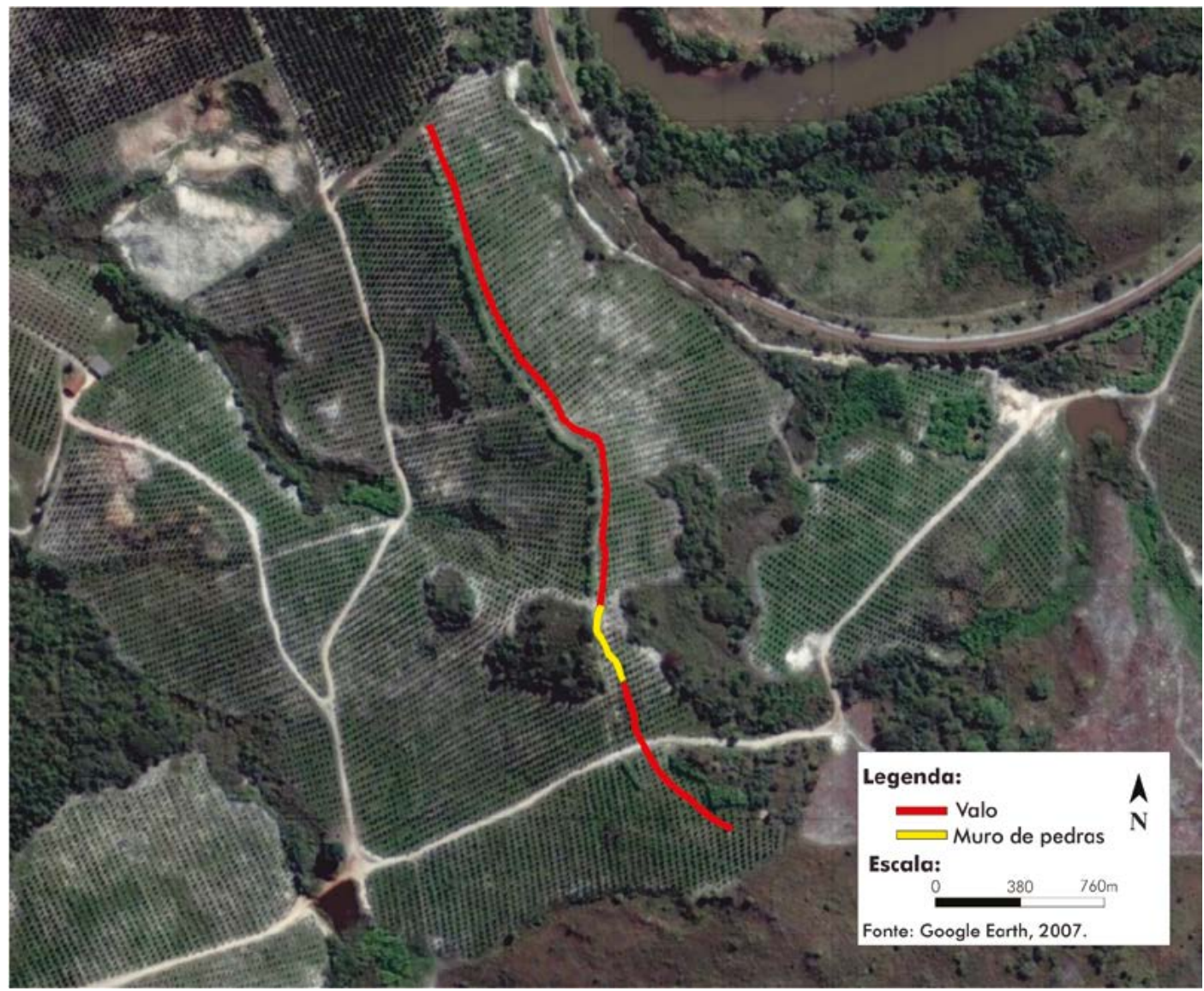

Imagem 12. Imagem de satélite do valo e muro de pedras. Sítio Arqueológico Chacrinha dos Pretos (Belo Vale, Minas Gerais). @2014 Google; SIO, NOAA, U.S. Navy, NGA, GEBCO; ๔ 2010 Maplink/ Tele Atlas; ๑ 2014.

4. Instituto do Patrimônio Histórico e Artístico Nacional (IPHAN) Processo n- $1428-T-98$ - Inscrição no Livro Histórico 563 11/07/2002.

5. Decreto nㅜ164/1999 - Inscrição no Livro Tombo Municipal no 01/1999.
Atualmente o terreno é utilizado para agricultura; a preparação do mesmo para o cultivo a plantação e a construção de uma estrada impactaram a integridade e o contexto dos vestígios arqueológicos, além da flora e fauna que interagem com os mesmos.

É possível perceber na imagem como o valo e o muro de pedras estão associados a fragmentos de vegetação. A profundidade atual do valo não é a original, já que sofreu ao longo do tempo um assoreamento que reflete um processo recorrente nos casos de ocorrência de tais tipos de vestígios.

Outro caso já referido que merece atenção é o fosso que circundava parte do antigo núcleo de ocupação do Quilombo do Ambrósio, implantado na primeira metade do século XVIII e localizado no atual município de Ibiá, Minas Gerais. O sítio é um Bem Cultural tombado em nível federal ${ }^{4}$ e em nível municipal ${ }^{5}$, sendo considerado por alguns documentos da época o maior que teria existido nas Minas Gerais até então.

O elemento arqueológico à primeira vista que se destaca no contexto do sítio é um fosso escavado no terreno, apresentando a forma de uma ferradura circundando uma área de 1,5 hectares, onde estava localizado o núcleo principal de ocupação (Imagem 13). A existência do fosso remete à necessidade de defesa considerando principalmente dois fatores: a repressão constante movida pelas autoridades escravistas coloniais contra os quilombos; e o fato 
de que a região, ainda, era habitada por grupos indígenas que poderiam eventualmente constituir uma ameaça para a comunidade quilombola.

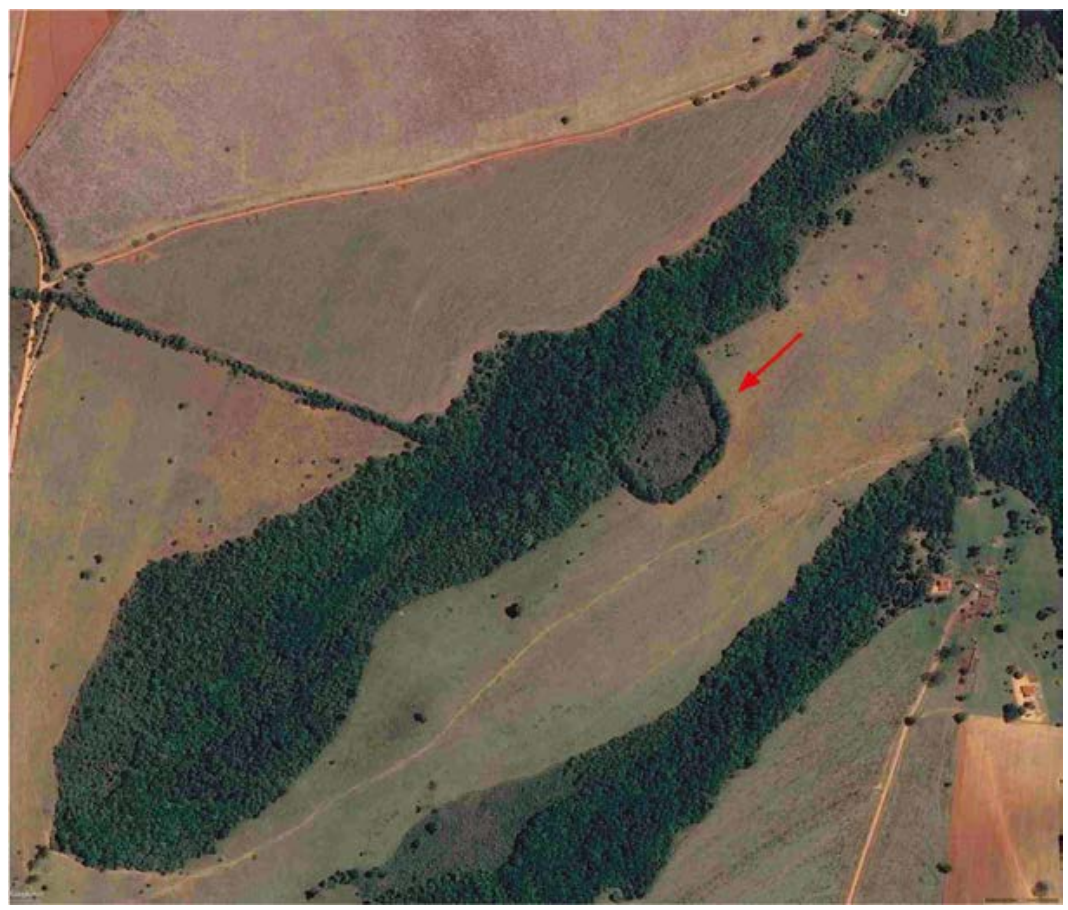

Imagem 13. Imagem de satélite da região com o núcleo do Quilombo (Ibiá, Minas Gerais). (c) 2016 Google; SIO, NOAA, US. Navy, NGA, GEBCO; ๔ 2016 Maplink/ Tele Atlas; ๑ 2016 Digital Globe.

Sondagens realizadas na área protegida pelo fosso, no final da década de 1980, evidenciaram vestígios de moradias -construções de pau-a-pique com piso de barro alisado-, fragmentos de recipientes cerâmicos e restos alimentares -como sementes e fragmentos de espigas de milho.

Atualmente, o fosso apresenta em seu interior uma vegetação bastante robusta (Imagem 14). Como anteriormente mencionado, os cortes em formatos de trincheiras -criando níveis diferentes da declividade original do terrenopossibilitaram o acúmulo de matéria orgânica e de nutrientes, favorecendo o desenvolvimento da vegetação.

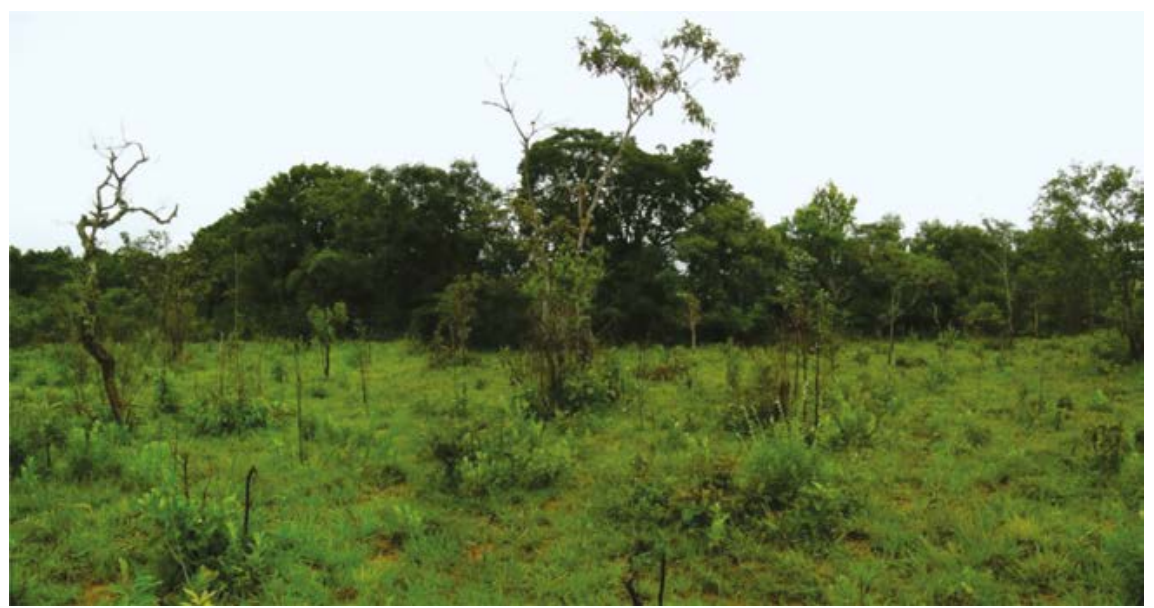

Imagem 14. Vegetação no interior do fosso (vista externa). Sítio Arqueológico Quilombo do Ambrósio (Ibiá, Minas Gerais). 
O ambiente do fosso serve também de habitat para fauna local, bem como possibilita a biodiversidade da flora. A imagem de satélite evidencia a flora presente no interior do fosso e sua conexão com um fragmento de vegetação maior (Imagem 13). A vegetação no interior do fosso de alguma forma pode ter contribuído para a preservação dos vestígios arqueológicos encontrados na área circundada por ele.

Finalmente, outro caso que merece referência pela diversidade de elementos associados à mineração e à perspectiva aqui desenvolvida é o sítio arqueológico denominado Forte de Brumadinho. Foi no contexto colonial, em sua fase áurea, que teria sido implantado este que foi o núcleo de uma grande unidade minerária. O destaque no conjunto arqueológico fica para a fortaleza que teria sido a sede do empreendimento e que hoje dá o nome ao sítio arqueológico.

Trata-se de uma fortificação com muros de pedras, muitas delas de grandes dimensões, associada a vestígios de tanques e mundéus, canais, plataformas arrimadas, muros e escoramentos de pedras, galerias de minas, uma grande cava de encosta, trilhas e segmentos de estradas calçadas, dentre outros. É um imenso complexo de vestígios que permitem uma visão bastante clara de uma unidade de exploração minerária e de seu funcionamento.

É um sítio exemplar através do qual é permitido compreender as formas de interação e adaptação do ser humano com o meio natural -explorado e impactado-, além de ter integrado o contexto da atividade minerária desenvolvida durante o período colonial na região das Minas Gerais. E isto faz do Forte de Brumadinho um dos mais importantes sítios arqueológicos do período colonial de Minas Gerais.

A fortificação é uma grande estrutura delimitando uma área de formato quadrangular irregular (60,0 m x 40,0 m) -o que indica uma mão-de-obra especializada e em quantidade suficiente para os trabalhos de deslocamentos e preparação -cantaria- das peças (Imagem 15).

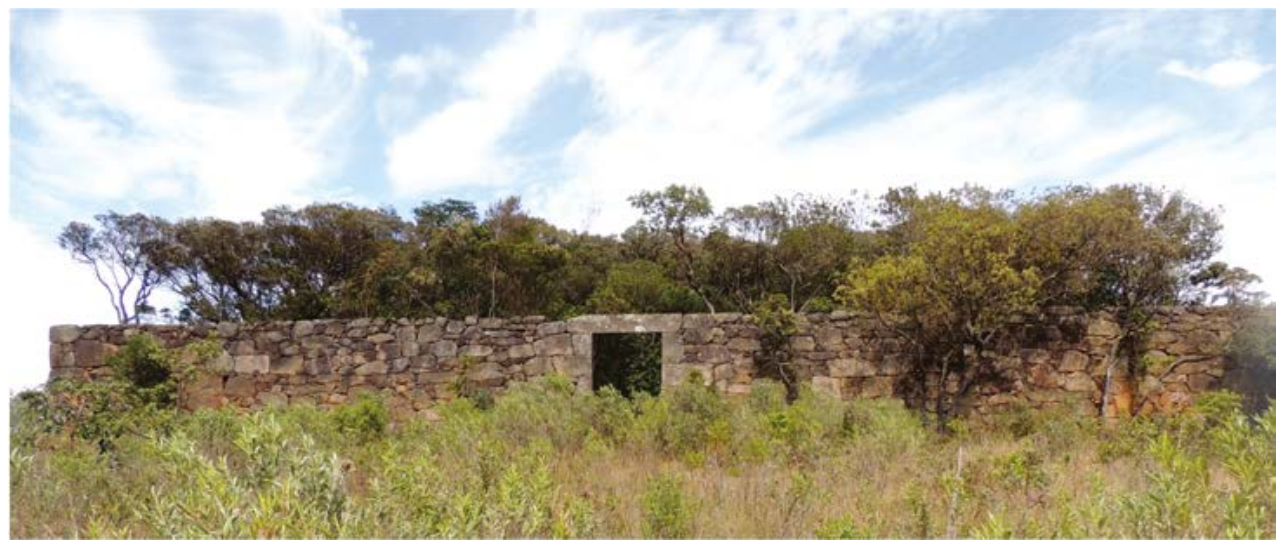

Imagem 15. Forte de Brumadinho (Brumadinho, Minas Gerais), vista frontal.

6. Consistia na abertura de grandes cavas com o intuito de atingir o sedimento a ser explorado.
$\mathrm{Na}$ área em frente ao Forte um dos destaques é um conjunto de quatro plataformas escalonadas, associadas a dois tanques e uma grande área de lavra -cava. Explorada pelo método do "talho a céu aberto" ${ }^{\prime}$ a expansão da cava vai do topo à base do morro, sendo os tanques utilizados para armazenamento da água que -posteriormente- seria direcionada para a lavra, permitindo o desmonte com a transformação do sedimento em lama aurífera (Imagens 16 e 17). 


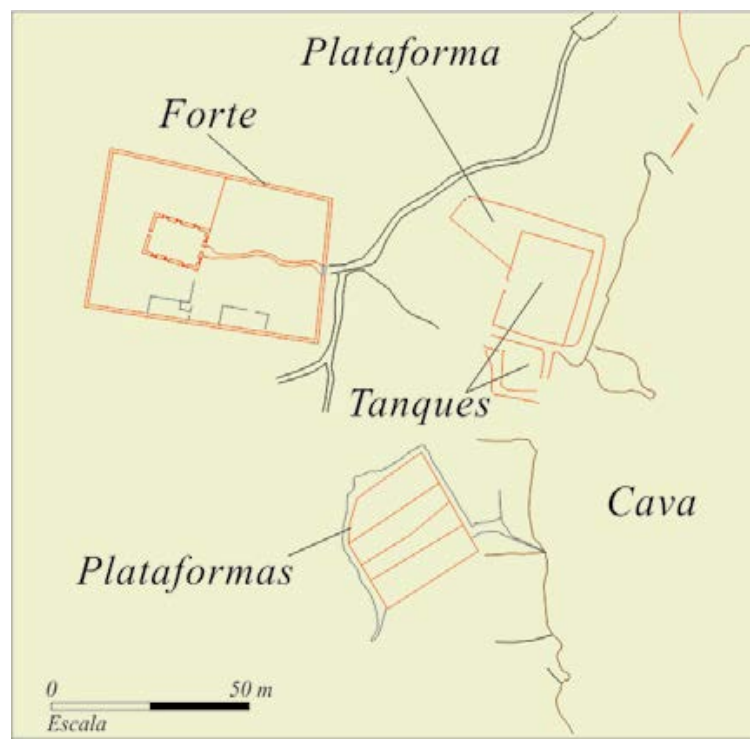

Imagem 16. Planta parcial do Sítio Arqueológico Forte de Brumadinho (Brumadinho, Minas Gerais).

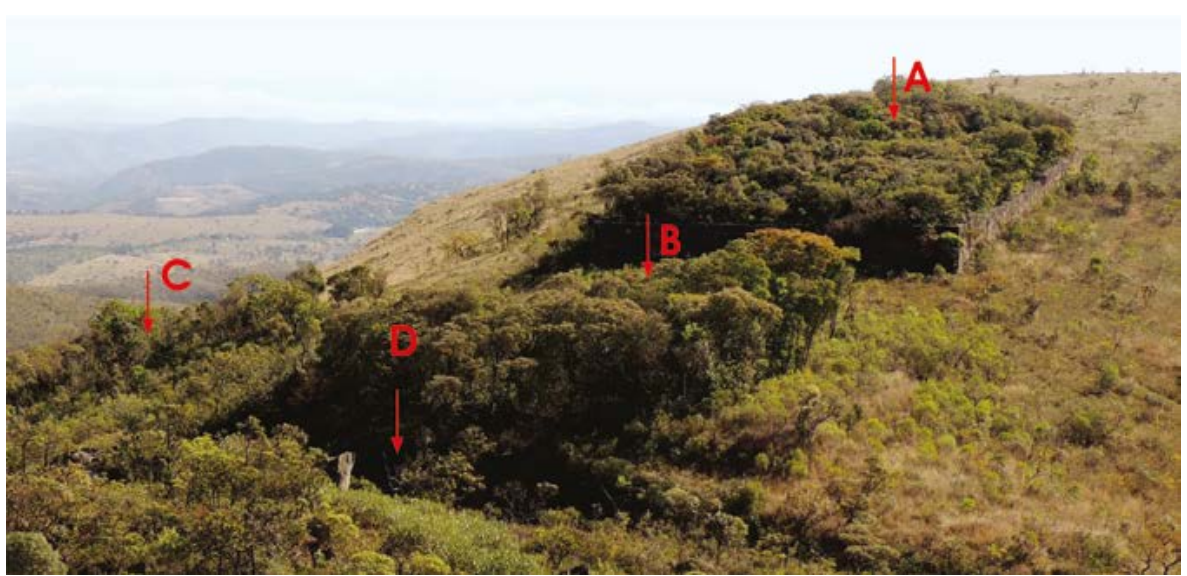

Imagem 17. A) Forte; B) Tanques; C) Conjunto de plataformas e D) Cava. Sítio Arqueológico Forte de Brumadinho.

Com relação às plataformas escalonadas, embora a aparência do conjunto não permita identificar de imediato sua função, é possível que as mesmas tenham sido bases para edificações, como senzalas -ou ranchos-, ou ainda utilizadas para outras atividades da unidade produtiva. Não pode ser descartado também seu uso para cultivo.

A mata secundária que atualmente recobre o sítio é um importante elemento de proteção dos vestígios arqueológicos. Ela os protege de agentes como o sol e o vento atuando também para manter a umidade e a temperatura do ambiente dentro de determinados limites. Além disso, as muralhas da fortaleza ajudam a proteger seu interior das queimadas anuais que constituem ameaça grave, chegando a atingir o sítio.

Se por um lado a vegetação protege os vestígios arqueológicos, por outro estes também são um agente de preservação, na medida em que permite a recuperação e preservação da flora/ fauna nas áreas onde estão presentes. Para o caso do Forte de Brumadinho é notável como as concentrações e o desenvolvimento da vegetação ocorrem predominantemente nas áreas dos 
vestígios arqueológicos, como no interior do Forte, dos tanques, da cava de mineração e no conjunto de plataformas escalonadas.

Para o vigoroso ambiente florestal formado no interior da Fortificação contribuem a planificação da topografia e as paredes, que formam uma barreira contra queimadas e os fenômenos provocados pelo efeito de borda. Tal efeito é caracterizado por mudanças abióticas, como a maior ação eólica, as altas temperaturas e a baixa umidade, que favorecem menor diversidade, menor porte, menor permeabilidade, menor diâmetro médio das espécies arbóreas, maior espaçamento entre os indivíduos de maior diâmetro e a predominância de espécies pioneiras.

A superação do efeito de borda permitiu o crescimento de frondosos exemplares e a formação de um ecossistema específico no interior do Forte (Imagem 18) e no conjunto de vestígios localizados à sua frente. A partir deste novo ecossistema foram criados outros habitats, os quais apresentam significativa presença de fauna -inclusive carnívoros de topo de cadeia-, que utilizam o local como abrigo, área de nidificação e alimentação (Imagem 19).
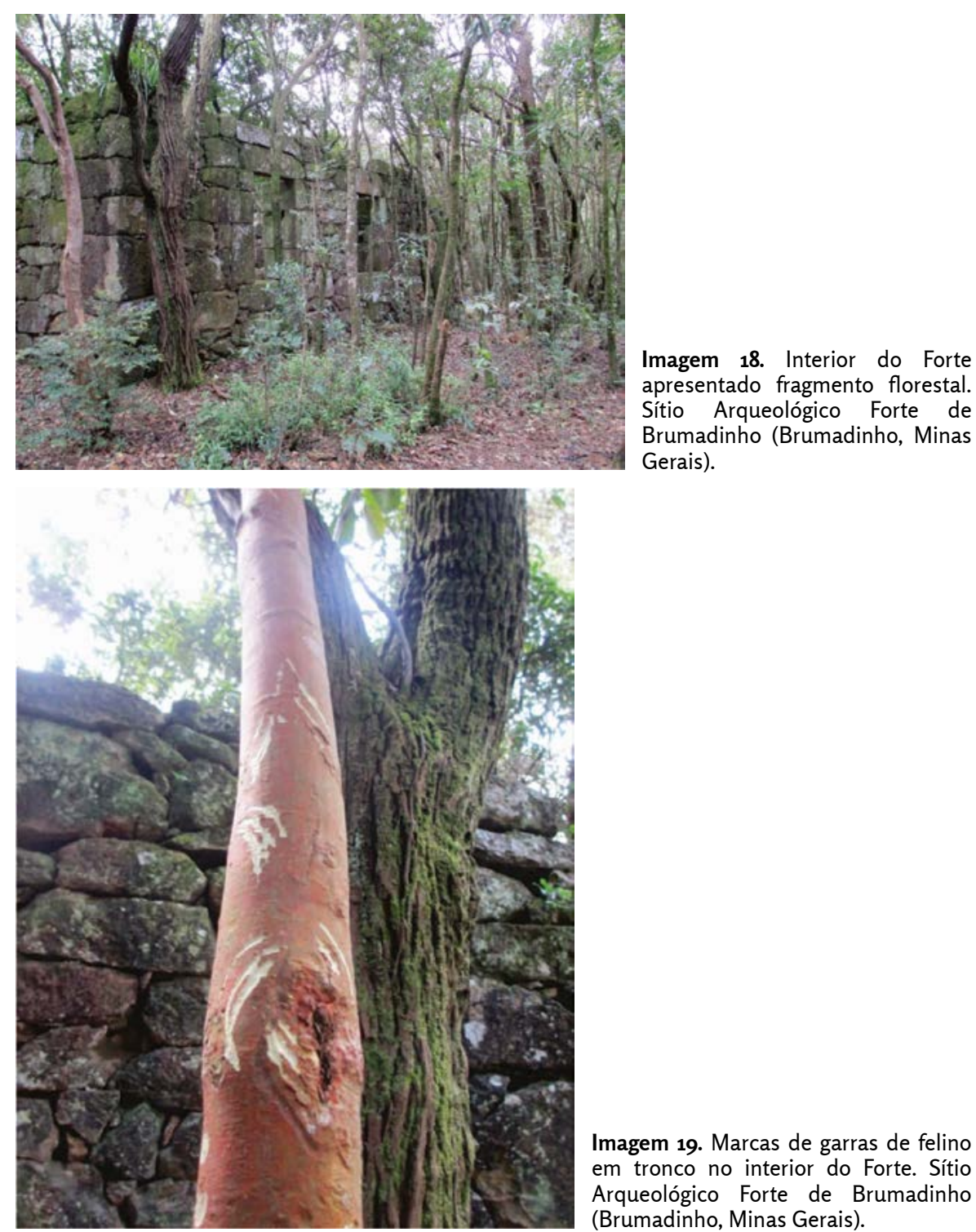

Imagem 19. Marcas de garras de felino em tronco no interior do Forte. Sítio Arqueológico Forte de Brumadinho (Brumadinho, Minas Gerais). 
O desenvolvimento de árvores de grande porte no interior das estruturas arqueológicas e a diversidade de espécies registradas (Imagem 20) indica que a origem da mata ocorre como uma sucessão ecológica natural.

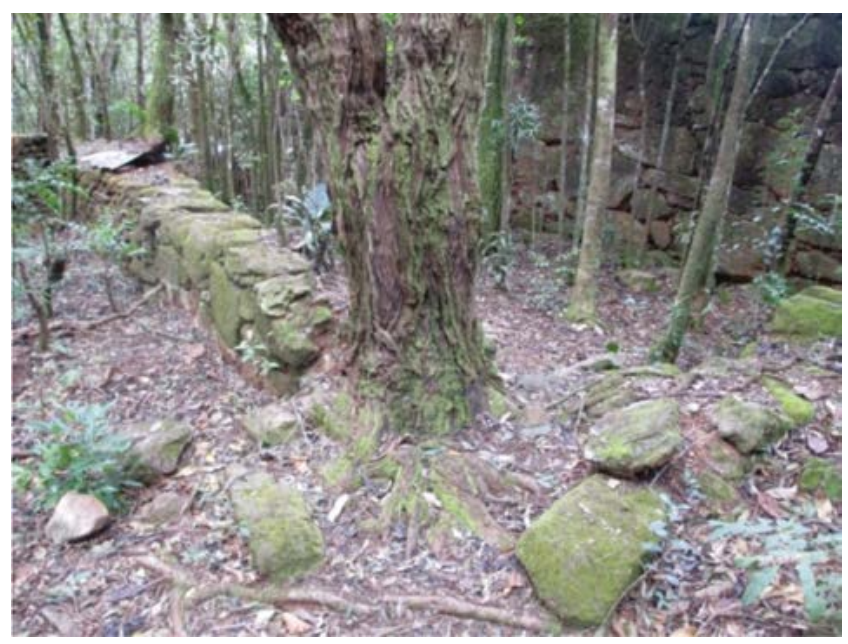

Imagem 20. Interior do forte: árvore de grande porte na extremidade do segmento de muro de pedras. Sítio Arqueológico Forte de Brumadinho (Brumadinho, Minas Gerais).

As imagens de satélite mostram como os vestígios arqueológicos constituem como uma barreira contra incêndios, principalmente na fortificação onde a proteção das paredes para a vegetação preservada é mais evidente (Imagem 21). A primeira imagem -de 2010- mostra a área do Forte de Brumadinho após uma queimada e permite a constatação de que a presença das paredes deixou intacta a vegetação em seu interior. O mesmo ocorreu com outras áreas como os tanques, as plataformas e a grande cava.

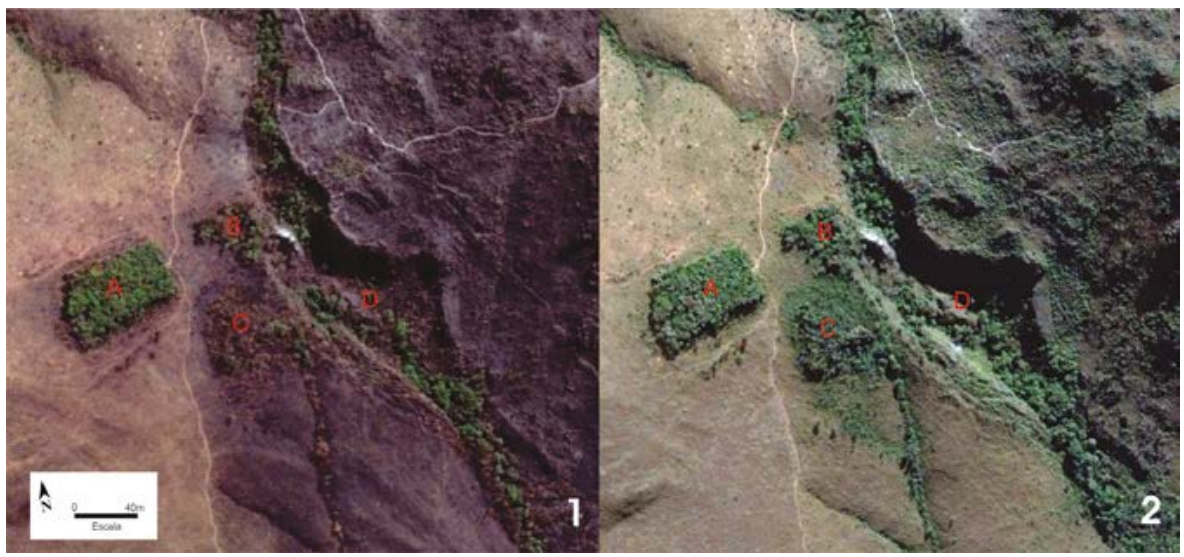

Imagem 21. 1) Imagem de satélite do sítio Forte de Brumadinho após queimada anual (Brumadinho, Minas Gerais). ๑ 2010 Google; SIO, NOAA, US. Navy, NGA, GEBCO; ๔ 2010 Maplink/ Tele Atlas; ๔ 2010 DigitalGlobe. 2) Imagem de satélite do mesmo sítio antes de queimada proposital. A- Forte; B- Tanques; C- Plataformas e D- Cava. ๑ 2012 Google; SIO, NOAA, US. Navy, NGA, GEBCO; ๔ 2012 Maplink/ Tele Atlas; $\odot 2012$ DigitalGlobe.

A vegetação nestas estruturas foi parcialmente impactada pela queimada, mas quando comparada à do entorno é inegável como os vestígios arqueológicos contribuíram para sua preservação. E é nesse sentido que determinados tipos de vestígios funcionam como instrumentos de recuperação e preservação de ecossistemas. 
7. A Etnobotânica entendida como o estudo das sociedades humanas, passadas e presentes, e suas interações ecológicas, genéticas, evolutivas, simbólicas e culturais com as plantas. (Alexiades, 1996).
Com relação à vegetação no interior do Forte, a introdução de espécies vegetais alóctones, visando sua utilização cotidiana ainda no século XVIII, não foi constatada, mas certamente algumas das espécies autóctones -existentes na área- podem ter sido largamente utilizadas na época, em decorrência de suas características etnobotânicas ${ }^{7}$ conhecida pelas culturas tradicionais.

\section{Considerações finais}

A partir do exposto cabem algumas considerações no tocante à articulação entre determinados tipos de vestígios arqueológicos e aspectos da realidade ambiental na qual eles estão inseridos.

O primeiro aspecto a ser referido é a natureza dialética da relação entre os dois elementos citados acima. Se por um lado determinados tipos de vestígios arqueológicos permitem que no seu contexto a natureza se recupere das ações impactantes de origem antrópicas; por outro, esta recuperação cria condições mais adequadas de preservação dos vestígios arqueológicos. É um processo bilateral no qual se beneficiam tanto a natureza quanto o patrimônio arqueológico.

O segundo aspecto é a constatação de que o citado processo é duplamente positivo, mas a sua ocorrência não se deve à ação antrópica. Por um lado, a recuperação ambiental é uma dinâmica implementada pela natureza e só ocorre após o abandono do sítio e sua consolidação enquanto vestígio arqueológico. Lamentavelmente, em grande parte das situações identificadas a presença de visitantes em sítios arqueológicos vem contribuindo para a sua destruição. O caso do Forte de Brumadinho é um exemplo de descaso em que os visitantes que acampam no interior do Forte estão sistematicamente destruindo o ambiente e o complexo arqueológico.

A partir dos dois aspectos referidos acima decorre um terceiro: a necessidade de que a legislação que visa proteger o patrimônio ambiental e arqueológico contemple a interação entre os dois a partir do processo descrito ao longo deste trabalho.

Dito de outra forma é necessário que a legislação esteja voltada para a necessidade de proteger os vestígios arqueológicos, não só por sua natureza específica, mas por ser ele um fator ou agente de defesa do patrimônio ambiental. Proteger os valos, muros, açudes, tanques, edificações, cavas antigas etc., é uma ação que pode certamente está contribuindo para a preservação da biodiversidade tão impactada nos dias de hoje. Que o digam os desastres e crimes ambientais.

\section{Agradecimentos}

Gostaríamos de agradecer ao Conselho Nacional de Desenvolvimento Científico e Tecnológico (CNPq) e à Fundação de Amparo à Pesquisa do Estado de Minas Gerais (FAPEMIG) pelo apoio em diferentes momentos do desenvolvimento desta pesquisa. 


\section{Referencias bibliográficas}

" Alexiades, M. (1996). Selected guidelines for ethnobotanical research: a field manual. New York, New York Botanical Garden.

"Castro, G. (1993). “Ecologia da Vegetação de Corredores Ecológicos Naturais Originários de Valos de Divisa". Tese de Doutorado em Engenharia Florestal. Universidade Federal de Lavras (UFL). Minas Gerais, Brasil.

"Castro, G. C. (2004). "Análise da estrutura, diversidade florística e variações espaciais do componente arbóreo de corredores de vegetação na região do Alto Rio Grande, Minas Gerais". Dissertação do Mestrado em Engenharia Florestal, UFL. Minas Gerais, Brasil.

" Guimarães, C. M. (1988). Os quilombos do século do Ouro (Minas Gerais, século XVIII). Estudos Econômicos 18 (número especial): 7-43. São Paulo, Universidade de São Paulo (USP).

》 Guimarães, C. M. (1995). Quilombos e Política (MG Século XVIII). Revista de História 132: 69-81. São Paulo, USP.

" Guimarães, C. M. (1996). “Mineração, Quilombos e Palmares - Minas Gerais no século XVIII" em Reis, J.J \& F. S. Gomes, Liberdade por um fio. História dos quilombos no Brasil: 139-163. São Paulo, Companhia das Letras.

》 Guimarães, C. M. \& L. M. Reis (1986). Agricultura e escravidão em Minas Gerais (170o/ 1750). Revista do Departamento de História 1 (2): 7-36.

» Guimarães, C. M. \& F. M. da M. Reis (2007). "Agricultura e Mineração no século XVIII" em Resende, M. E. L \& C. L. Villalta, História de Minas Gerais: as Minas setecentistas, vol.1. Belo Horizonte, Ed. Autêntica.

" Moraes, F. B. de (2007). "De arraiais, vilas e caminhos: a rede urbana das Minas Coloniais" in Resende M. E. L. de \& L. C. Villalta (coords.), História de Minas Gerais: As Minas Setecentistas 1: 55-85. Belo Horizonte, Ed. Autêntica/ Ed. Companhia do Tempo.

"Paiva, E. F. (2002). "Bateias, carumbés, tabuleiros: mineração africana e metiçagem no Novo Mundo" en Paiva, E. F. \& C. M. J. Anastasisa (orgs.), $O$ trabalho mestiço; maneiras de pensar e formas de viver - séculos XVI a XIX: 187-207. São Paulo/ Belo Horizonte, Annablume/ PPGH-UFMG

》 Reis, F. M. da M. (2007). "Entre faisqueiras, catas e galerias: explorações do ouro, leis e cotidiano nas Minas do século XVIII (1702-1762)". Dissertação Mestrado em História. Belo Horizonte, Fafich /UFMG

» Resende, M. E. L. \& L. C. Villalta (2007a). História de Minas Gerais: as Minas setecentistas. Belo Horizonte, Autêntica. (Vol. 1).

» Resende, M. E. L. \& L. C. Villalta (2007b). História de Minas Gerais: as Minas setecentistas. Belo Horizonte, Autêntica. (Vol. 2).

》 Rugendas, J. M. (1998). O Brasil de Rugendas. Rio de Janeiro, Itatiaia. 